\title{
Identifying "Occasions" of the Self in Viking-Age Scandinavia: Textile Production as Gendered Performance in Its Social and Spatial Settings
}

\begin{abstract}
This contribution interrogates the gendered self in a Viking-Age, Scandinavian context. It proposes that the performance of a particular craft, weaving, may have created "occasions" for different experiences of the self, when conducted in different social and spatial settings. Through the analysis of the distribution of the archaeological remains from textile production at selected settlement sites, it is possible to associate specific spaces in buildings to this activity, and to situate it within households of different social statuses. As a result, the experiences of distinct groups of women are revealed through the different settings, both social and architectural, for the performance of a stereotypically gendered activity. This performance therefore appears imbued with very different meanings, hereby leading to varied experiences of the social self. The character of the activity itself, which is repetitive as well as physically and technically demanding, may have contributed to a deeply embodied sense of self, even in the seemingly mundane arena of everyday life.
\end{abstract}

Keywords: social space, textile production, gender, setting, embodied performance, occasionalism, experience of the self

Can we imagine a form of human experience without a sense of self? By focusing on the Middle Ages, the contributions in this volume highlight how historically contextual the understanding and expression of the self is, but also how its cognitive and psychological dimension may transcend cultures across time and space. The concept of the self is closely intertwined with that of the individual. The historiography of individualism and individuality has variously placed the birth of the individual in the Renaissance, the French and Industrial Revolutions, or the twelfth-century medieval renaissance (Bagge 1997; see also the editors' Introduction in this volume). Does that mean that there was no individual prior to any of those dates? The usual cues for investigating this question are seemingly

Sarah Croix, Aarhus University

Ә Open Access. (C) 2020 Sarah Croix, published by De Gruyter. (c) BY-NC-ND This work is licensed under a Creative Commons Attribution-NonCommercial-NoDerivatives 4.0 International License.

https://doi.org/10.1515/9783110655582-012 
absent from contemporary sources for the Viking Age in Scandinavia: there are no autobiographies or commissioned portraits, and dress styles are mainly known from funerary contexts, where their wearers were clothed by others. On the other hand, runic inscriptions including personal names and carved on functional objects provide a rather unique insight into Viking-Age selfexpressions and stresses the involvement of material culture in this process (see also Karen Holmqvist, this volume).

Rather than seeking to identify and analyze expressions of the self, this contribution proposes an intellectual exercise, assuming the existence of some form of self in this period and hypothesizing which occasions would have triggered a particular experience of the self's own sense of agency in a Viking-Age, Scandinavian context. In this chapter, a stereotypically gendered activity, textile production, will be seen as circumscribing a group of social actors. The different settings for the performance of this activity, dwellings and small, halfsubterranean outbuildings also known as sunken-featured buildings at various types of settlements, will be closely studied in order to discuss and distinguish possible variations in how the performance of the same activity may have led to different experiences of the self.

\section{Theoretical Background}

From a philosophical and psychological point of view, the "self" can be considered as the experience and expression of one's awareness of one's own form of individuality. This process operates as a negotiation, as it involves the individual distinguishing and/or assimilating with significant others and larger social groups. This results in three forms of self, the individual, the relational, and the collective, all three co-existing in the individual (Sedikides and Brewer 2002). The perception of the self is thus not fixed but dialectically and contextually variable, and it is closely connected to a sense of agency and the ability to choose, control, and see one's actions as one's own - and to the fact of being denied such ability (e.g., Hohwy 2006). As a result, it is a social phenomenon, which cannot emerge in isolation. While psychological and emotional experiences, tastes, and interpretation of cultural norms can be shared with others, experiences of the self are perceived as being unique. The body, which both binds the self to the material world and allows us to be "in the world" (see Merleau-Ponty 1945), creates a privileged arena for experiencing and representing the self, but recent debates about the "finiteness" of the body has also challenged the notion of the individuality of the self (van Wolputte 2004). 
From a philosophical point of view, this understanding of the self is in parts inspired by Erwin Goffman's The Presentation of Self in Everyday Life (1959). Although criticized on various occasions, his proposal remains useful to explain the individual's efforts to handle social relations through impression management, which may vary depending on the degree of intimacy between the actors involved (Raffel 2013). Furthermore, appearances are not always mere façade; postmodernist theory considers that such performances and experiences can even become world-building and reality-shaping (see Austin 1962). Any social interaction involves communication, which is necessarily codified to be understandable. Using theatrical play as metaphor for social behavior, Goffman paints daily life as a performance where social actors use pre-established roles suitable in the given situation in order to achieve the desired effect. Understanding the self as situational allows for different and even contradictory "selves" within one individual. From this, we can extract the notion of a form of duality in the presentation of self, which is both constricted and enabled by role-play, whether that be intentional / conscious or involuntary / routinized. Goffman also stressed how social actors try to influence perception of their behaviors through setting (the stage), appearance (the costume), behavior (body language, voice tone), etc. This means that architectural spaces, understood as settings, provide the "stage" for the presentation of the self through performance, and variation in setting allows for different expressions and experiences of the self, including the gendered self.

The theory of performativity has had a major impact on the humanities since the 1990s, especially regarding gender studies. Judith Butler in particular has discussed gender as being something that not simply "is" but something that is enacted (Butler 1990). While her work has been criticized on various fronts, including for lacking scholarly ethics and for disengaging with actual feminist issues (e.g., Nussbaum 1999), one of her main contributions has been to stress how gender is constituted and becomes "real" through repeated associations or citations, especially the performance of bodily practices, but also "real" in the moment, through the selection, adaptation, and rejection of socially expected roles and attributes culturally defined as gendered. The involvement of material attributes for the recurrent practices leading to the construction of gender affords an entryway for archaeologists to explore this matter in past societies (e.g., Joyce 2004; Sørensen 2006).

The "performative turn" has also led to a variety of approaches in historical studies (Burke 2005) and has raised the question of individual agency and the possibility of "negotiating" within the broader frameworks of social structures, mainly addressed by microhistory. For Peter Burke, the main contribution of this trend has been, by acknowledging flexibility of behavior in relation to norms, to shed light on what he has called "occasionalism" - the fact that "on different 
occasions (moments, locales) or in different situations, in the presence of different people the same person behaves differently" (Burke 2008, 97-98). Inspired by these various theoretical and historiographical trends, the approach of the present contribution is thus based on the premises that the self is multiple, relational, and variable according to settings and audiences; that the gendered self is performative, and that performance is reality-shaping; that performance involves bodily practice and material culture, following codes and norms in order to be understandable; and that the self can be circumscribed by identifying "occasions" during which specific performances led to specific experiences of the self.

\section{Finding the Self in Settlement Contexts}

There are inherent challenges to studying the self on the basis of archaeological remains, which revolve around the nature of archaeological data. Very often, archaeology is poorly equipped to individualize actors behind the formation and deposition of physical remains. Even in mortuary contexts, where the presence of human bodies may give us the impression of a close encounter with past individuals, we often remain confronted with their anonymity and passivity. Increasingly, however, archaeology is able to reconstruct bits of individual biographies containing particular life experiences by applying natural scientific techniques to the study of human remains (Elise Naumann, this volume).

In Viking-Age Scandinavia, settlement sites can be considered as the primary economic and domestic unit, a place where most people's social and work life unfolded within the frame of the household (see Egil L. Bauer in this volume for a medieval, urban case). In these contexts, the archaeological remains are both intentional (for example, the cutting of a hole in the ground to place an upright post in it or the dumping of waste in specifically assigned areas) and functional (lost artifacts and most ecofacts) (see, e.g., Eggert 2001, 105-21). Besides its relationality, the experience of self is one that pertains to the individual. The archaeological remains of everyday life in settlement contexts appear to us as a palimpsest of actions performed by a range of anonymous actors, which are virtually impossible to separate (for a general discussion of the nature of the archaeological data, see, e.g., Schiffer 1976, 1987, 2010; Binford 1981; Lucas 2012). Instead of distinct individuals with their own experiences and paths, we are typically dealing with a more diffuse aggregate of agents: a larger, anonymous collective. Contrary to funerary contexts, where we assume that the actions of the mourners are intentional and that we may be able to decipher these intentions, the degree of intentionality and self-expression behind the actions which led to the deposition of artifacts 
and structures in the ground at settlement sites is often less obvious. For example, was there any statement of self behind the dumping of a bucket of ash in a midden? Should we read in it the frustration of an angry teenager who was sent to take out the trash and who demonstratively dumped it right in front of the door?

Technological knowledge and its application to the fabrication of an object may in some cases allow seeing intentionality and individuality in an everyday, settlement setting. Most pottery used in Viking-Age settlements was the result of domestic production. As such, it belongs to the habitus but is not immune to stylistic innovation (e.g., Roslund 2001; Naum 2012). The potter would repeat an established pattern ("this is how a proper pot should look") while introducing some personal elements to variable degree based on knowledge, experience, taste, and intended purpose. These traits may have been even more salient for manufactures of greater technological complexity, such as the casting of copperalloy jewelry. The identity of the manufacturer is unknown, but his or her self may still be perceptible in the style of the object. Studies of styles in the manufacture of metal ornaments at the early towns suggest different "schools" producing the same type of objects with distinct stylistic and technical elements (Sindbæk 2011; Pedersen 2015). This may reflect the traditions and innovations of distinct workshops, the skills, know-how, and creativity of individual artisans. In this context, the hand of the artisan may be more telling about his or her self than his or her name. Manufacture is also a highly embodied practice involving a range of sensual and physical experiences provoked through interaction with the matter that is being transformed.

To sum up, it is nearly impossible to disentangle individual actions through the archaeological remains of settlements, and by virtue of this, to identify the performance and experience of the self on a day-to-day basis in the Viking Age based on the archaeological evidence. However, this does not necessarily imply an absence of "self" in this context. Approaching the self through technology as a unique, embodied performance located in the social setting of the household may provide a fruitful avenue to investigate how the self's own sense of agency may have been experienced in Viking-Age Scandinavia.

\section{Textile Production as Female Stereotype}

The gendered self is one particular form of self-experience. While this does not allow separating particular individuals in the archaeological remains of settlements, identifying gendered experiences, to which particular markers and roles 
may be attached, may allow seeing if not individual, at least narrowed down and more specific experiences of self. The runic objects bearing personal names mentioned in the introduction contain both female and male names, suggesting that both men and women could express their selves through this particular mode of expression.

Considering the difficulties in pinpointing individualized experiences of self, we are left to speculate about what would be a typical gendered experience of self, in other words, which socially and culturally defined roles and attributes were available to social actors in order for them to negotiate their own gendered self in the Viking Age. This question has and continues to animate research (for a recent overview, see Moen 2019), and there is no room here to review the various interpretations of who did what in Viking-Age Scandinavia. Based on my previous research (Croix 2012), in the following I will be working on the premise that the idea of (at least) a male as well as a female gender existed in the Viking Age, to which were commonly associated a range of distinct social roles. Among them, I would argue that, if textile production was not exclusively performed by women - that is, social individuals understood as belonging to the female gender, and that not all women were involved in this production - it was at least thought of as being associated to the female gender.

Textile production was one of the most important forms of production in early medieval northwestern Europe, for clothing and domestic equipment, ranging from sacks for transport to tapestries with detailed narratives (e.g., Rogers 2007; Netherton and Owen-Crocker 2005) and, especially in a Scandinavian, Viking-Age context, sail production (Andersson 1999; Andersson 2003). The scale and complexity of the production, involving a range of actors and processes on a daily basis and year-round, implies that it had broad ramifications throughout the social matrix. It can also be considered as part of the female stereotype. This association is indeed recurrent, though not exclusive, in many Viking-Age contexts: in burials (Croix 2012, 60-61, and references therein), on runic objects (e.g., inscription N 582 on spindle-whorl from Uppstad, Aust-Agder: "Helga owns this spindle-whorl": Norges innskrifter med de yngre runer, 5:198-9; on runic objects and personal names in runic inscriptions, Imer 2007; Peterson 2007), and kennings (e.g., vefGefn \{the weaving-Gefn <= Freyja> [WOMAN], stanza 7; Poetry from the Kings' Sagas 2009, 2:94-6; on kennings, Meissner 1921).

While runic objects relating to ownership appear embedded in daily practice, funerary rituals and skaldic poetry represent arenas for social negotiations and idealized representations, meant to be performed in front of an audience in order to, among other things, commemorate known people and deeds (e.g., Oestigaard and Goldhahn 2006; Williams 2013; Guðrún Nordal 2012). While some elements of the performance may evoke these facts rather directly, both commemorative forms use 
various poetical means to highlight particular roles and attributes pertaining to their referents: the objects involved in the mortuary ritual acts and the kennings. Both have been seen as referring to known stories of mythological character (Price 2010; Marold 2012, lxxxiv-lxxxv), thus acting as a form of eulogy. The kennings existed independently from the poetical context in which they were used (Marold 2012, lxxxii) and, while some obtained their meaning from referring to known stories, others seem to have been constructed based on an observable, recurring pattern. As such, they played on existing stereotypes, using attributes available within the cultural repertoire and widely understood within their cultural context to provide basic information about their referents. The attitudes and values displayed in representational contexts thus refer to codes, symbols, and norms, which would have been expected, known, and understood. This implies that, even though sociological studies suggest that stereotypes are often more rigid than reality, they remain to some extent bound to an observable pattern, which may not be absolute, but which repeats itself sufficiently to create a relatively stable association (Krueger, Hasman, Acevedo, and Villano 2003; Kite, Deaux, and Haines 2008). Therefore, it is through the repeated association between the female gender and the fabrication of textiles that the doing of the second became a stereotypical role for the first, hereby creating an arena through which a gendered self could be experienced in Viking-Age Scandinavia.

\section{The Setting of Performance: Spaces of Textile Production}

Different settings may have led to variable experiences of self, and the household, composed of individuals of different gender, status, and age, provided the main social arena for the performance and experience of self on a daily basis in Viking-Age Scandinavia. This makes dwellings and attached buildings at Viking-Age farmsteads the main setting for the experience of a gendered self. The functions of these buildings, their architectural features, temporality, accessibility, and degree of visual integration all created distinct settings for the performance of daily activities, which may have affected the experience of their users. Through the careful analysis of the spatial distribution of textile tools at rural settlement sites from Viking-Age Scandinavia, spinning and weaving, two key elements of textile production, appear to have been performed both inside sunken-featured buildings and dwellings. The significance of this observation can be discussed further by considering three main examples. The first deals with how textile production was performed in different settings on the same 
farmstead, thus affecting the experience of self as more relational or intimate, and the second with how a particular social setting can have created a particular occasion for representing oneself. Finally, the third raises the question of whether the co-existence of different settings implies the existence of different experiences of gendered selves intersecting with social status.

The performance of textile working inside dwellings is relatively well attested on Viking-Age agrarian settlements, despite often problematic preservation conditions or degree of archaeological documentation, both in today's Denmark, for example at Vorbasse, or in the Scandinavian diaspora in Iceland, for example at Aðalstræti and Vatnsfjörður (Croix 2012, 171-9; Croix 2014, 120-2; see also Hvass 1980, 2011; Milek 2006, 2012; Milek and Roberts 2013). While spindle-whorls can be found scattered in different rooms, weaving tends to be associated with the main dwelling room in the center of the house. Usually, the loom would have been placed in a corner of the room. There are some obvious practical reasons for this. It is a rather large object, which is not easily moved once it is set up, and it is best to keep it out of the way. It also needs to lean against a wall, so it has its necessary place in a peripheral position, and although weaving requires some light, it may have been best to keep the loom away from the open fireplace. Generally speaking, the main dwelling room of a Viking-Age longhouse is a rather large and open space with a high degree of visual integration. The occurrence of weaving in this setting suggests an activity which was integrated, together with those who were engaged in it, in the daily routine of the household. Even if it did not involve all its members, all were certainly aware of it. The performance of this activity in this particular context may have led to experiencing one's social self in negotiation with social stereotypes and of one's position in the household.

In some instances, sunken-featured buildings associated specifically with textile production are found on the same farmsteads as those where the activity was also attested in dwellings, such as in the examples mentioned above. It has been argued that sunken-featured buildings offer highly suitable conditions for weaving, in terms of light and relative dampness, as they are partly under ground level (Zimmerman 1982, 133), but obviously, these conditions were not an absolute necessity. As a rule, the chronology of these buildings is no further assessed than belonging to the same phase of settlement, which is often roughly defined as spanning a period of 50-100 years or more. Whether textile production was moved from one space to the other cannot be assessed at present, and the two settings for this activity, the main dwelling area and the sunken-featured building, appear to have been used simultaneously. Assuming that this is true, how should it be understood? There may be differences of status within the household, implying that the activity was attributed different meanings depending on who performed it, and as a result, implying different locations for its production. It may also be the same 
persons using both spaces at different times. In this case, the setting may have contributed to a particular experience of the gendered self. Although not a strictly secluded space as such, the sunken-featured building, through its small dimensions, low degree of accessibility, and functional specialization, was the arena for only limited forms of social encounters. Therefore, besides being architecturally two very different structures, the main dwelling room and the sunken-featured building offered very different possibilities in terms of integration of textile production in the daily routine of the household as a whole. We can wonder if this situation indicates two different experiences of self for the same women: between an essentially social and relational self, defined in a dialectical manner in relation with other members of the household in a collective setting; or a more individual self, where the performance of weaving may have led to a more personal experience of self, triggered by isolation or intimate interaction with the few other individuals present engaging in the same activity.

The question of the social significance of textile production becomes more explicit when considering the dwellings of the social elite. Archaeology often discusses the elite self in terms of status, which needs to be expressed by using various markers and symbols (for example conspicuous consumption). This is based on the assumption that the elite is particularly concerned with asserting its status and has therefore a more acute sense of self and need for self-representation. The positioning of the elite towards social norms can be seen as that of the extreme, either following them to the letter, which makes good sense, as they are the same norms that allow them to be on top, or by challenging them entirely, hereby asserting that they can do so without negative consequences. Either way, it reflects a prominent sense of self, balancing between the pros and cons of individuality and collectivity. Few Viking-Age buildings illustrate the representation of the social elite as prominently as the longhouse at Borg in Lofoten (Herschend and Mikkelsen 2003). Its monumental construction and ostentatious display of wealth leave little doubt about the elevated social position of its household. The central room of the building has been interpreted as a hall with representational functions, inspired by the images of festivities inherited from the medieval Icelandic literary sources. It is also a rather open space, with a high degree of visibility. At the same time, it appears as a multi-functional space hosting domestic activity, in contrast with more specialized hall buildings as known in South Scandinavia.

There are, however, some differences from the dwellings of the more "regular" farmsteads. The loom is, as usual, placed along a wall, but not in a corner. Instead, it is located in a more central position, very close to the central fireplace (Croix 2011, 119-21, Fig. 1). Considering the assumed representational functions of this room, it likely provided the setting for social gatherings where hierarchies 


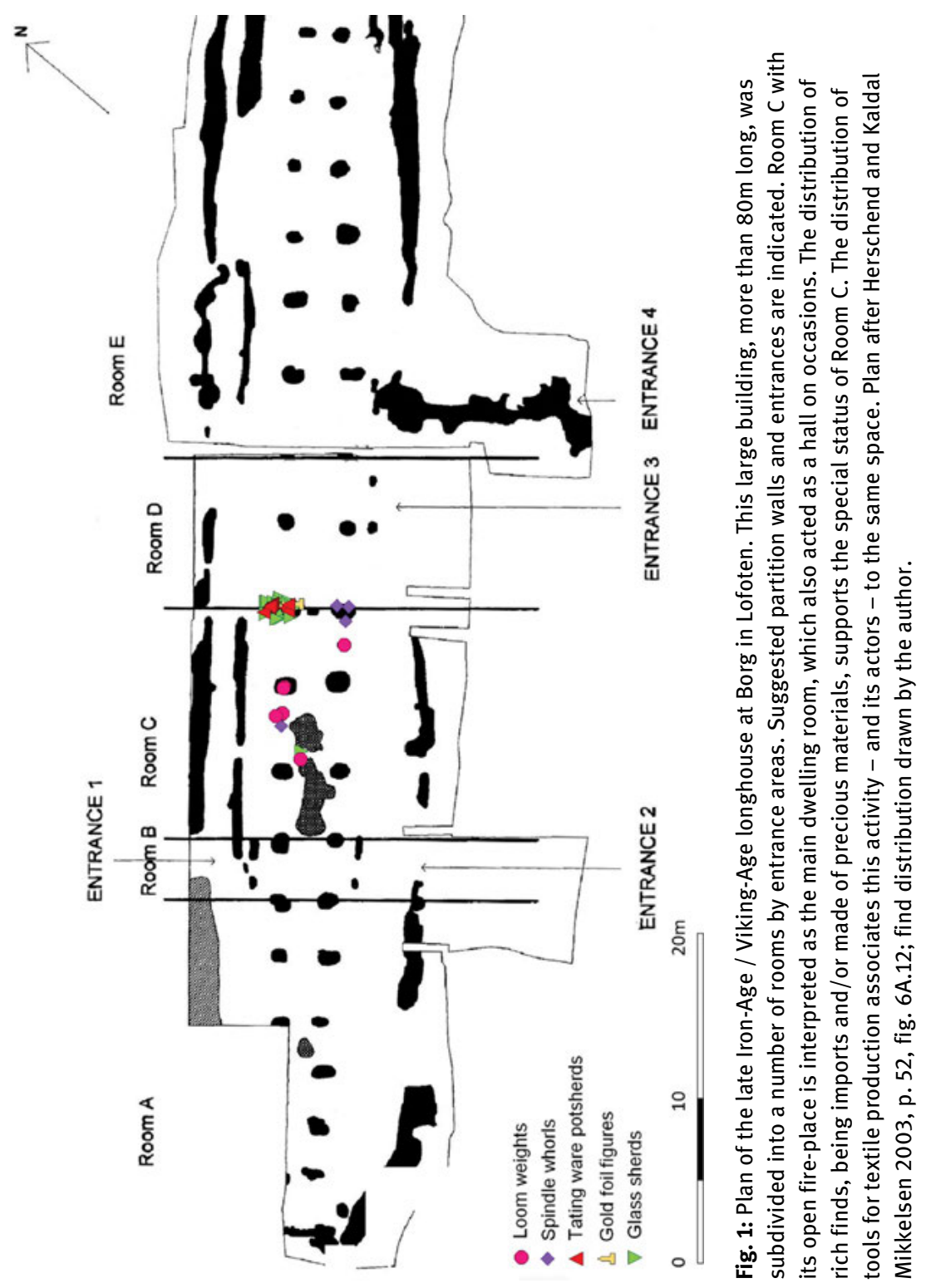


and social relations were negotiated and put on display. Perhaps the loom was removed in those occasions - but what if it was not? The use of the loom in a kenning for women hints at the fact that the stereotype and norm of women weaving was to be understood and accepted in the higher spheres of society to whom skaldic poetry was most frequently dedicated. Therefore, the loom may have been left standing in a central, visible position, stressing the adhesion of the highest-ranked women in the household to social standards - and perhaps on these occasions only, leaving the care for daily production to others. The respect for conventions may have been a means of self-representation for women of the elite.

While social differences may not be readily observed within single settlements such as the farmsteads described earlier or the elite building of Borg in Lofoten, they may be revealed through the more complex socio-spatial organization of a settlement like Aggersborg (Roesdahl, Sindbæk, and Pedersen 2014), where textile working is attested in different settings (Croix, Roesdahl, and Jørgensen 2014, 377-8). Before the construction of the large ring-fortress in the later part of the tenth century, the site by the Limfjord consisted of several farmsteads (Sindbæk 2014, 109-32, Fig. 2), where textile working is attested in the main dwelling room, as often seen at agrarian settlements. There was also a larger longhouse, house $\mathrm{D}$, the construction of which did not differ markedly from the other farmhouses apart from its dimensions, dominant position in the landscape, longevity, and its more exclusive modes of consumption (Sindbæk 2014, 116-21, Fig. 3). The activity of weaving is attested in the main dwelling room, as at Borg in Lofoten, while that of spinning is encountered spread throughout the house. Further downhill, there was a large landing site used on a seasonal basis with hundreds of sunken-featured buildings and evidence for market and craft production (Sindbæk 2014, 133-47; Brown, Goodchild, and Sindbæk 2014), including textile production.

These different building forms, connected with different lifestyles (including temporalities, mobilities, modes of consumption, etc), created particular settings for individuals, who most likely belonged to different social groups. On the one hand, one can find the social elite, living in the largest longhouse on top of the hill and the households with the agrarian lifestyle; on the other hand, the seasonal visitors, staying in the sunken-featured buildings for the period of time it took them to perform what may have been enforced labour. In this context, the performance of fabricating textiles may have contributed to the experience of a particular sense of self. For women of higher status living in the longhouse on top of the hill, weaving may have meant little more than the assertion of their gendered self in relation to the collective norms of their social group, as at Borg in Lofoten, with some but likely not decisive economic significance. For the 


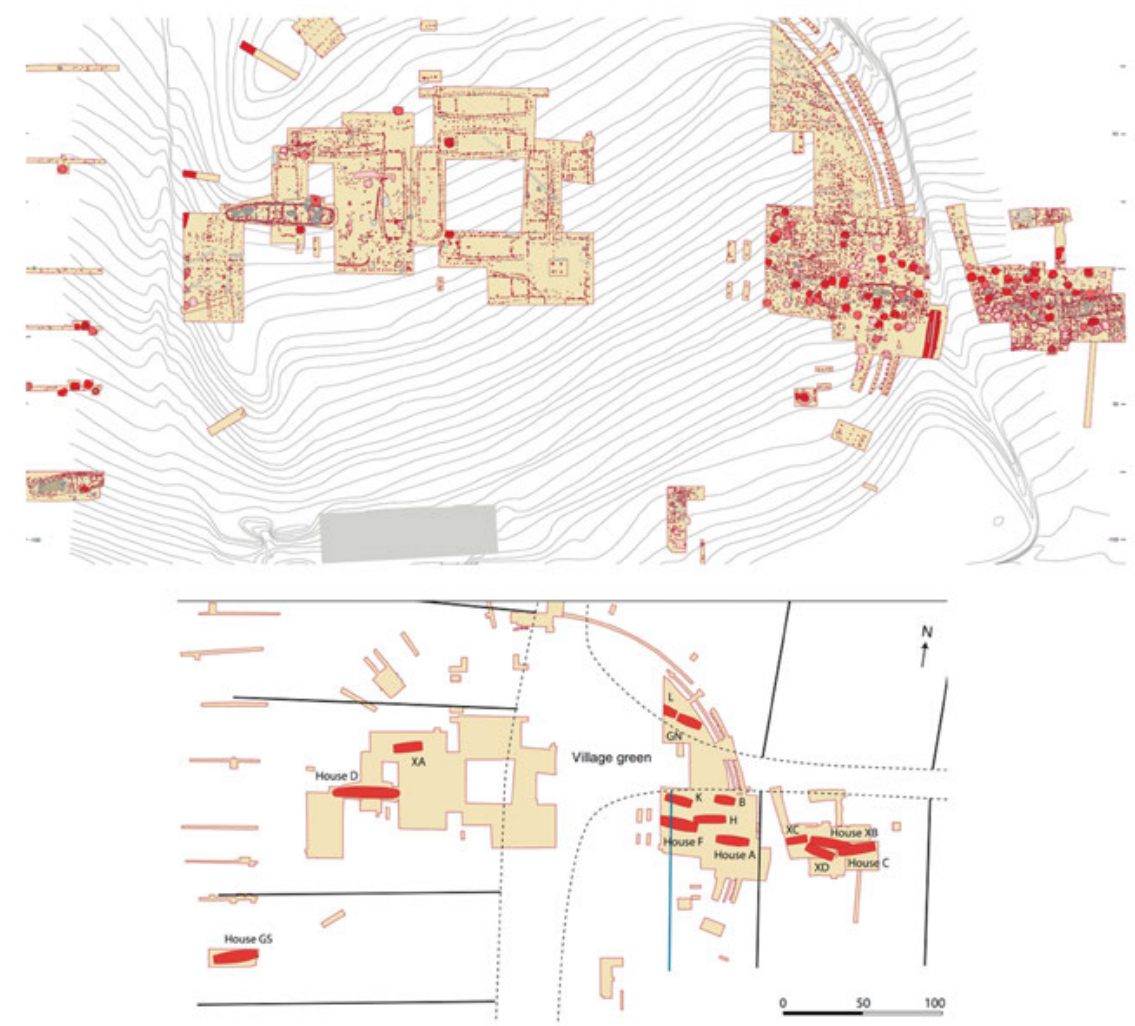

Fig. 2: Aggersborg in the Viking Age. (above) The Viking-Age occupation at Aggersborg has left a palimpsest of archaeological features associated to different phases, the latest of which was a huge circular fortress. The pre-fortress settlement included a large number of sunkenfeatured buildings (red fill). Magnetometer surveys suggest that hundreds more of these small buildings should be added to the existing figures, especially in the area to the south. The topography of the area features a gentle slope from the north towards the shores of the Limfjord to the south. (below) From the pre-fortress settlement a number of post-built longhouses, probably from farmsteads, were identified. The vast majority of the sunkenfeatured buildings belongs to the same phase. Above: After Roesdahl, Sindbæk, Pedersen \& Wilson (ed.) 2014, plate 2; below: after Sindbæk 2014, p. 135, fig. 4.55.

women living on the farmsteads, in Denmark or in Iceland, it may have been part of a daily routine, integrated in the life of the household and its economy of subsistence, contributing to asserting their role in the household and their relation to their significant others. For those who stayed for a season in sunkenfeatured buildings along the shore, however, textile production may have meant coerced and strenuous work, associated with yearly recurring periods away from 


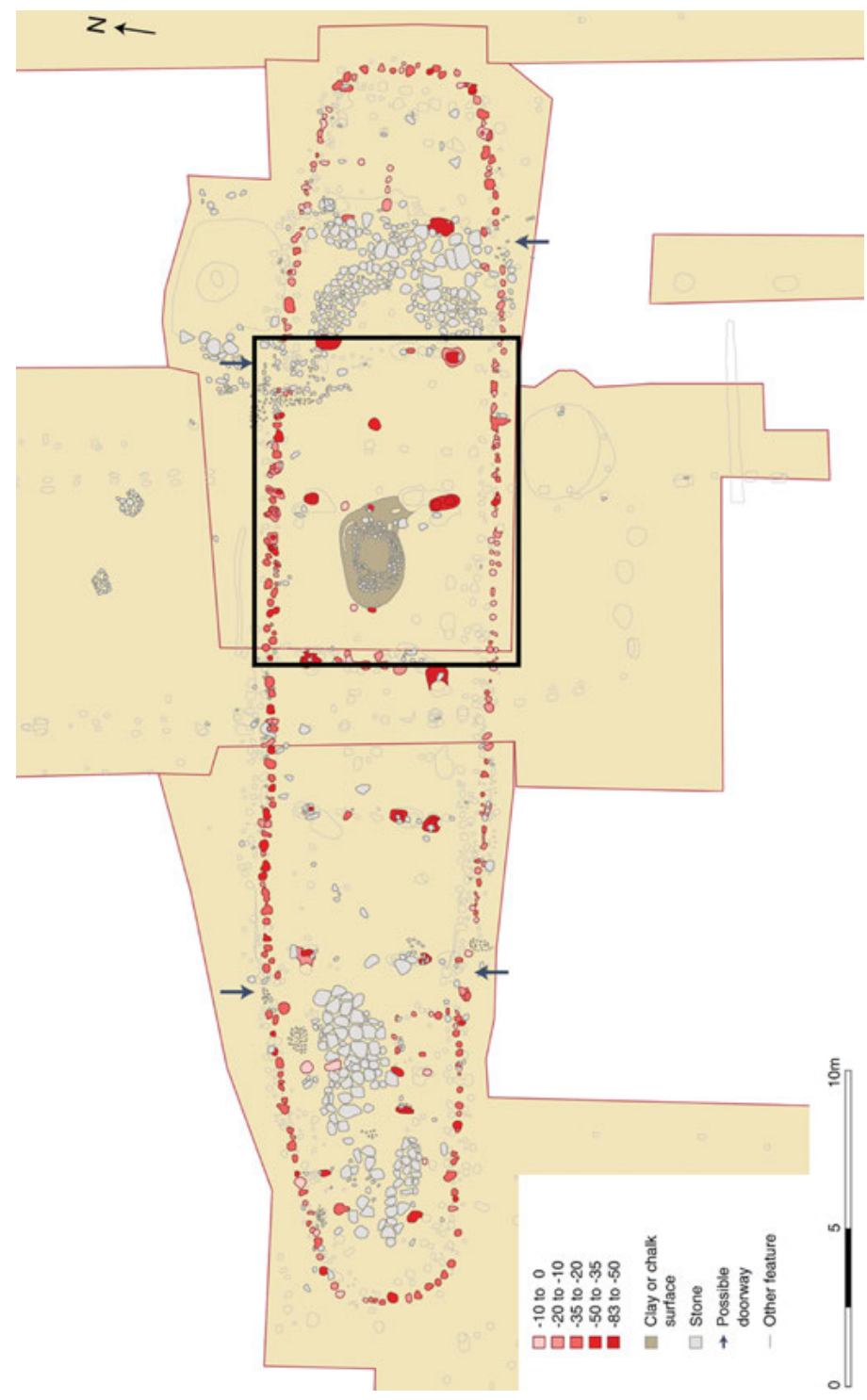

Fig. 3: Aggersborg - house D. The Viking-Age longhouse was probably the main building of a magnate's farm. It was 40 meters long and divided into rooms with various functions including a stable/byre to the west. The main dwelling room (in the black frame) was equipped with a fire-place on the median axis, and the distribution of tools for textile production throughout the building indicates that weaving most likely took place there. The depth of postholes is indicated by shades of red. After Sindbæk 2014, p. 95, fig. 4.13. 
"home," and potentially leading to a degraded sense of self linked with a denial of their individual agency. The experience of the gendered self which has been outlined here is thus a correlate of the individuals' social status, which defines specific frameworks in which their sense of agency may be facilitated or inhibited through the performance of the same activity taking different meanings depending on who, where, and for which purpose it was conducted.

\section{Textile Working as Performance}

These examples illustrate settings and "occasions" during which a specific dimension of the self may have been experienced in Viking-Age Scandinavia - a gendered self, intersecting with social status. Textile working as the physical performance through which this experience was activated may in itself have contributed to it. Indeed, it is an embodied practice requiring technical knowledge, creativity, and experience. The weaving process on an upright, warp-weighted loom involves the repeated lateral movement of the weft, probably attached to some kind of shuttle, moving back and forth between the warp (Hoffmann 1964). The warp, heavily weighed down by the loom-weights in two sheds or more, is also moved back and forth after each lateral movement of the weft. The weft is set into place using a goblin pin, a weaving comb, or a weaving batten, made of wood, iron, or whalebone. The width of a Viking-Age warp-weighted loom can be estimated to $c .1 .20-2.00 \mathrm{~m}$. This is narrow enough for a single person to be able to slide the weft throughout the width of the warp from one end of the weave to the other, but it cannot be excluded that a second person was involved. The setting up of the loom was certainly more easily achieved by more than one person. Based on a series of reconstructions and calculations, it has previously been suggested that it would take one person at least 2 years to produce a $25 \mathrm{~m}^{2}$ sail (Strand 2015, 16) and 9 years for a $112 \mathrm{~m}^{2}$ sail for a Viking-Age warship (Jørgensen 2012, 178) - a daunting and time-consuming task, which would have required some form of "industrialized" production and cooperation.

Besides a range of sensory experiences connected to the work (the contact with the wool or the linen, its smell, the relative darkness and possibly dampness of the working environment), there are two elements in weaving which make it a particular physical and, through this means, mental experience: its strenuousness and its repetitiveness. The tightening of the weft to its correct place using a weaving batten may have felt rather physically demanding, considering the tension and resistance of the weave and the weight of the instrument. The loom-weights as a complete set were also rather heavy, and their weight would have been felt each 
time the shed was moved back and forth. While the shuttle in itself is not heavy or difficult to slide through the warp, its lateral movement is repetitive to say the least. A good-quality weave should ideally be as uniform and regular as possible, with the same thread count per centimeter throughout. Monotonousness is, in this case, a desired goal. A patterned weave introduces some variation, but a rhythmic, mathematically calculated one. Together, strenuousness and repetitiveness make weaving a performance conducted and experienced through the body.

The role of textile working in relation to a particular experience of the self in modern, Western culture, in which this activity is conducted for pleasure and without economic necessity, has been considered within the framework of occupational science (Riley 2008). In this study, textile-making is linked to an enhanced sense of self, enabled by the process of creative doing and the identification as a textile-maker, and to a collective sense of self, as the occupation is conducted within the framework of a community through which knowledge is also transmitted. The rhythmical repetitiveness of weaving has even been described as "a form of flow, where the body is in harmony with the mind" (Riley 2008, 70; see Csikszentmihalyi 1990).

It is not only in modern, Western culture that this dimension of textile working has been linked to a metaphysical, religious experience. The making of altarpieces or "enclosed gardens," using, among other materials, textiles, by sixteenth-century female religious communities in the Low Countries and the Rhineland has been interpreted as "a practice of sensory and devotional meditation" (Baert 2016). In the same context, spinning seems to have been seen as a meditative activity, within but also beyond religious communities (Dlabačová 2018). The meditative effect of spinning may emerge from the repetitiveness of the practice, allowing the subject to get closer to the divine through the alignment of soul and body in a similar way as prayer beads allowed during personal devotion (Heilskov 2019).

Although this notion is suggested within a Christian, medieval context, and is not directly applicable to the cultic practices, world-views, and ontologies of pre-Christian Scandinavia, it does highlight how strenuous, repetitive bodily performance can place the subject into a particular state of mind. In this manner, textile working represents an experience which is bound to the individual through their body and, therefore, potentially, to their sense of self. Would this practice also have allowed meditative or metaphysical experiences in Viking-Age Scandinavia? In this context, the eleventh-century skaldic poem Darraðarljóð, preserved in the thirteenth-century Njáls Saga, springs to mind (Poole 1991, 116-56). In the poem, a group of valkyries appears to be deciding of the course and outcome of a battle (traditionally identified as the Battle of Clontarf in 1014) as they weave on a warp-weighted loom, where the loom-weights are human 
skulls and warp and weft are intestines. While the weaving process has been seen as mere metaphor for the battle, it is tempting to see the repetitive movement of the weft following the rhythm of the poetical form, thus combining the spoken word to the creative performance, as a form of sympathetic magic, in which ritual transformation achieves transformation in the worldly sphere.

\section{Conclusion}

Inspired by performance and gender theories and the "performative turn" in historical research, I have sought in this chapter to identify "occasions" during which female individuals may have experienced various dimensions of their self in everyday contexts in Viking-Age Scandinavia. Textile production has been selected as a stereotypical female activity based on a varied set of contemporary evidence. Spinning, and weaving in particular, involved a bodily performance, which could be located in the architectural space of Viking-Age settlement sites based on the distribution of related artifacts in dwellings and sunken-featured buildings documented archaeologically. In this way, it has been possible to show how this activity took place in different settings and for different audiences, and to correlate this performance to various social conditions. By both respecting and confronting societal norms, the performance of the same activity by different groups of individuals at different occasions may have led them to experience different forms of self. Mundane daily activities can therefore be considered as an important part of the experience of self. While the same activities may be performed by many, the settings in which they were performed and by whom gave them different meanings, hereby creating different experiences of the self for those involved, which could be both unique to the individual and similar to those of the collective. The strenuousness and repetitiveness of the work may also have led to an enhanced or a diminished sense of self, depending on the significance and outcome of the work for the practitioner. While the focus of the present contribution has been on the physical, performative dimension of textile production, it would equally be relevant to consider the economic, social, and symbolic significance of textile products of different qualities, forms, styles, and levels of complexity. Could these be considered as forms of self-expressions, thus enlightening a different dimension of the Viking-Age self? 


\section{References}

\section{Primary Sources}

Norges innskrifter med de yngre runer. 1941. Ed. Magnus Olsen, Aslak Liestøl, Ingrid Sanness Johnsen, and James Knirk. 6 vols. Oslo.

Poetry from the Kings' Sagas 2: From c. 1035 to c. 1300. 2009. Ed. Kari Ellen Gade. Skaldic Poetry of the Scandinavian Middle Ages, 2. Turnhout.

\section{Secondary Sources}

Andersson, Eva. 1999. The Common Thread. Textile Production during the Late Iron Age Viking Age. Lund.

Andersson, Eva. 2003. Tools for Textile Production from Birka and Hedeby. Stockholm.

Austin, John L. 1962. How to Do Things with Words. Oxford.

Baert, Barbara. 2016. "Instrumentalities and the Late Medieval 'Enclosed Gardens' of the Low Countries." Kunst og Kultur 99.3: 132-8.

Bagge, Sverre. 1997. "The Individual in the Middle Ages and the Renaissance: Introduction." The European Legacy 2.8: 1305-1312. DOI: 10.1080/10848779708579851

Binford, Lewis R. 1981. “Behavioral Archaeology and the 'Pompeii Premise'." Journal of Anthropological Research 37.3: 195-208.

Brown, Hannah, Helen Goodchild, and Søren M. Sindbæk. 2014. "Making Place for a Viking Fortress: An Archaeological and Geophysical Reassessment of Aggersborg, Denmark." Internet Archaeology 36. DOI: 10.11141/ia.36.2

Burke, Peter. 2005. "Performing History: The Importance of Occasions." Rethinking History 9.1: 35-52.

Burke, Peter. 2008. What is Cultural History? 2nd ed. Malden.

Butler, Judith. 1990. Gender Trouble: Feminism and the Subversion of Identity. London.

Croix, Sarah. 2011. "Status, Gender and Space on High Status Settlement Sites from the Viking Age." In Archäologie in Schleswig / Arkæologi i Slesvig, Det 61. Internationale Sachsensymposion 2010, Haderslev, Danmark. Ed. Linda. Boye et al. Neumünster. 113-22.

Croix, Sarah. 2012. "Work and Space on Rural Settlements in Viking-Age Scandinavia Gender Perspectives." Unpublished doctoral dissertation, Aarhus University.

Croix, Sarah. 2014. "Houses and Households in Viking Age Scandinavia - Some Case Studies." In Houses - Shaping Dwellings, Identities and Homes: European Housing Culture from Viking Age to the Renaissance. Ed. Mette Svart Kristiansen and Kate Giles. Højbjerg. 113-26.

Croix, Sarah, Else Roesdahl, and Lise Bender Jørgensen. 2014. "Tekstilredskaber. Tekstilaftryk." In Aggersborg i vikingetiden. Landbebyggelsen og borgen. Ed. Else Roesdahl, Søren M. Sindbæk, and Anne Pedersen. Højbjerg. 367-78.

Csikszentmihalyi, Mihaly. 1990. Flow: The Psychology of Optimal Experience. New York. Dlabačová, Anna. 2018. "Spinning with Passion: The Distaff as an Object for Contemplative Meditation in Netherlandish Religious Culture.” The Medieval Low Countries 5: 177-209. 
Eggert, Manfred K. H. 2001. Prähistorische Archäologie: Konzepte und Methoden. Stuttgart. Goffman, Erwin. 1959. The Presentation of Self in Everyday Life. New York.

Guðrún Nordal. 2012. "Poetry and Society: The Circumstances of Skaldic Production." In Poetry from the Kings' Sagas 1: From Mythical Times to c. 1035. Ed. Diana Whaley. Skaldic Poetry of the Scandinavian Middle Ages, 1. Turnhout. xc-xciii.

Heilskov, Mads V. 2019. "Sacralising Perception: Rosary-Devotion and Tactile Experience of the Divine in Late Medieval Denmark." In Touching, Devotional Practices, and Visionary Experience in the Late Middle Ages. Ed. David Carillo-Rangel, Delfi I. Nieto-Isabel, and Pablo Acosta García. Aldershot. 71-93.

Herschend, Frands, and Dorte Kaldal Mikkelsen. 2003. "The Main Building at Borg (I:1)." In Borg in Lofoten: A Chieftain's Farm in North Norway. Ed. Gerd Stamsø Munch, Olav Sverre Johansen, and Else Roesdahl. Trondheim. 41-76.

Hoffmann, Marta. 1964. The Warp-weighted Loom: Studies in the History and Technology of an Ancient Implement. Oslo.

Hohwy, Jakob. 2006. "The Sense of Self in the Phenomenology of Agency and Perception." Psyche 13.1: 1-20.

Hvass, Steen. 1980. "Vorbasse: The Viking Age Settlement at Vorbasse, Central Jutland." Acta Archaeologica 50: 137-72.

Hvass, Steen. 2011. "Bebyggelse og politik i Danmarks vikingetid - udgravningerne i Vorbasse." In Nationalmuseets Arbejdsmark 2011. Copenhagen. 46-59.

Imer, Lisbeth. 2007. "Runer og runeindskrifter: Kronologi, kontekst og function i Skandinaviens jernalder og vikingetid”. Unpublished doctoral dissertation, University of Copenhagen.

Joyce, Rosemary A. 2004. "Embodied Subjectivity: Gender, Femininity, Masculinity, Sexuality." In A Companion to Social Archaeology. Ed. Lynn M. Meskell and Robert W. Preucel. Malden. 82-95.

Jørgensen, Lise Bender. 2012. "The Introduction of Sails to Scandinavia: Raw Materials, Labour and Land." In N-TAG TEN: Proceedings of the 10th Nordic TAG conference at Stiklestad, Norway 2009. Ed. Ragnhild Berge, Marek E. Jasinski, and Kalle Sognnes. Oxford. 173-81.

Kite, Mary E., Kay Deaux, and Elizabeth L. Haines 2008. “Gender Stereotypes.” In Women's Psychology. Psychology of Women: A Handbook of Issues and Theories. Ed. Florence L. Denmark and Michele A. Paludi. Westport, CT. 205-36.

Krueger, Joachim, Julie F. Hasman, Melissa Acevedo, and Paola Villano. 2003. "Perceptions of Trait Typicality in Gender Stereotypes: Examining the Role of Attribution and Categorization Processes." Personality \& Social Psychology Bulletin 29.1: 108-16.

Lucas, Gavin. 2012. Understanding the Archaeological Record. Cambridge.

Marold, Edith. 2012. “The Diction of Skaldic Poetry." In Poetry from the Kings' Sagas 1: From Mythical Times to c. 1035. Ed. Diana Whaley. Skaldic Poetry of the Scandinavian Middle Ages, 1. Turnhout. Ixix-xc.

Meissner, Rudolf. 1921. Die Kenningar der Skalden. Rheinische Beiträge und Hülfsbücher zur Germanischen Philologie und Volkskunde, 1. Bonn and Leipzig.

Merleau-Ponty, Maurice. 1945. Phénoménologie de la perception. Paris.

Milek, Karen. 2006. "Houses and Households in Early Icelandic Society: Geoarchaeology and the Interpretation of Social Space.” Unpublished Ph.D. thesis, University of Cambridge.

Milek, Karen. 2012. "The Roles of Pit Houses and Gendered Spaces on Viking-Age Farmsteads in Iceland." Medieval Archaeology 56.1: 85-130. 
Milek, Karen, and Howell M. Roberts. 2013. “Integrated Geoarchaeological Methods for the Determination of Site Activity Areas: A Study of a Viking Age House in Reykjavik, Iceland." Journal of Archaeological Science 40.4: 1845-65.

Moen, Marianne. 2019. "Challenging Gender: A Reconsideration of Gender in the Viking Age Using the Mortuary Landscape." Unpublished doctoral dissertation, University of Oslo.

Naum, Magdalena. 2012. "Ambiguous Pots: Everyday Practice, Migration and Materiality. The Case of Medieval Baltic Ware on the Island of Bornholm (Denmark)." Journal of Social Archaeology 12.1: 92-119.

Netherton, Robin, and Gale R. Owen-Crocker, eds. 2005. Medieval Clothing and Textiles I. Woodbridge.

Nussbaum, Martha. 1999. “The Professor of Parody.” The New Republic. February 22, 1999. https://newrepublic.com/article/150687/professor-parody (accessed April 17, 2020).

Oestigaard, Terje, and John Goldhahn. 2006. "From the Dead to the Living: Death as Transactions and Re-negotiations." Norwegian Archaeological Review 39.1: 27-48.

Pedersen, Unn. 2015. "Urban Craftspeople at Viking-age Kaupang." In Everyday Products in the Middle Ages: Crafts, Consumption and the Individual in Northern Europe C. AD 800-1600. Ed. Gitte Hansen, Steven P. Ashby, and Irene Baug. Oxford and Philadelphia. 51-68.

Peterson, Lena. 2007. Nordiskt runnamnslexikon. 5th ed. Uppsala.

Poole, Russel Gilbert. 1991. Viking Poems on War and Peace: A Study in Skaldic Narrative. Toronto Medieval Texts and Translations, 8. Toronto.

Price, Neil. 2010. "Passing into Poetry: Viking-Age Mortuary Drama and the Origins of Norse Mythology." Medieval Archaeology 54: 123-56.

Raffel, Stanley. 2013. "The Everyday Life of the Self: Reworking Early Goffman.” Journal of Classical Sociology 13.1: 163-78.

Riley, Jill. 2008. "Weaving an Enhanced Sense of Self and a Collective Sense of Self through Creative Textile-making." Journal of Occupational Science 15.2: 63-73.

Roesdahl, Else, Søren M. Sindbæk, and Anne Pedersen, eds. 2014. Aggersborg i vikingetiden: Landbebyggelsen og borgen. Højbjerg.

Roesdahl, Else, Søren M. Sindbæk, Anne Pedersen, and David M. Wilson, eds. 2014. Aggersborg. The Viking-Age settlement and fortress. Højbjerg.

Rogers, Penelope Walton. 2007. Cloth and Clothing in Early Anglo-Saxon England, $A D$ 450-700. CBA research report, 145. York.

Roslund, Mats. 2001. Gäster i huset: Kulturell överföring mellan slaver och skandinaver 900 till 1300. Lund.

Schiffer, Michael Brian. 1976. Behavioral Archaeology. New York.

Schiffer, Michael Brian. 1987. Formation Processes of the Archaeological Record. Albuquerque.

Schiffer, Michael Brian. 2010. Behavioral Archaeology: Principles and Practice. Sheffield.

Sedikides, Constantine, and Marilynn B. Brewer. 2002. "Individual, Relational and Collective Self: Partners, Opponents, or Strangers?” In Individual Self, Relational Self, Collective Self. Ed. Constantine Sedikides and Marilynn B. Brewer. Hove, UK. 1-4.

Sindbæk, Søren M. 2011. "Urban Crafts and Oval Brooches: Style, Innovation and Social Networks in Viking Age Towns." In Viking Settlements and Viking Society: Papers from the Proceedings of the Sixteenth Viking Congress, Reykjavik and Reykholt, 16-23 August 2009. Ed. Svavar Sigmundsson et al. Reykjavik. 407-21. 
Sindbæk, Søren M. 2014. "Landbebyggelsen.” In Aggersborg i vikingetiden. Landbebyggelsen og borgen. Ed. Else Roesdahl, Søren M. Sindbæk, and Anne Pedersen. Højbjerg. 103-84. Sørensen, Marie Louise Stig. 2006. "Gender, Things, and Material Culture." In Handbook of Gender in Archaeology. Ed. Sarah M. Nelson. Lanham. 105-35.

Strand, Eva Andersson. 2015. "Textile Production, Organisation and Theoretical Perspectives on Trade in the Scandinavian Viking Age." In Textiles and the Medieval Economy: Production, Trade, and Consumption of Textiles, 8th-16th Centuries. Ed. Angela Ling Huang and Carsten Jahnke. Oxford and Philadelphia. 8-22.

Williams, Howard. 2013. "Death, Memory, and Material Culture: Catalytic Commemoration and the Cremated Dead." In The Oxford Handbook of the Archaeology of Death and Burial. Ed. Liv Nilsson Stutz and Sarah Tarlow. Oxford. 195-208.

van Wolputte, Steven. 2004. "Hang on to Your Self: Of Bodies, Embodiment, and Selves." Annual Review of Anthropology 33: 251-69.

Zimmermann, W. Haio 1982. "Archaologische Befunde fruhmittelalterlicher Webhauser. Ein Beitrag zum Gewichtswebstuhl.” Jahrbücher der Männer vom Morgenstern 61: 111-44. 